Jahangirnagar University J. Biol. Sci. 3(1): 67-73, 2014 (June)

\title{
In vitro propagation of Andrographis paniculata Nees.-A threatened medicinal plant of Bangladesh
}

\author{
P.K. Roy \\ Plant Biotechnology and Genetic Engineering Division, Institute of Food and Radiation \\ Biology, Atomic Energy Research Establishment, G.P.O Box No-3787, \\ Dhaka-1000, Bangladesh
}

\begin{abstract}
An efficient protocol was developed for in vitro regeneration of plantlets from shoot tip and nodal segment explants of Andrographis paniculata Nees. Nodal segment explants produced the highest number of shoots $(18 \pm 1.24)$ when they were cultured on MS supplemented with 11.10 $\mu \mathrm{M} / \mathrm{l} \mathrm{BAP}$. Addition of $10 \%$ coconut water and $2.0 \mathrm{~g} / \mathrm{l}$ activated charcoal to the above mentioned medium increased the number of shoots (30) per culture. Shoot tip explant also showed better performance in the same medium. Addition of $100 \mathrm{mg} / \mathrm{l}$ urea and $2.0 \mathrm{~g} / \mathrm{l}$ activated charcoal to the medium showed proper shoot elongation. The isolated shoots rooted well $(90 \%)$ on half-strength MS fortified with $9.80 \mu \mathrm{M} / 1 \mathrm{IBA}$, where average number of roots per shoot was 28-30. The plantlets were acclimatized successfully in poly bags containing a mixture of soil, sand and compost in 2:1:1 ratio. Finally acclimatized plantlets were transferred to experimental field.
\end{abstract}

Key words: In vitro propagation, multiple shoots, Andrographis paniculata Nees.

\section{INTRODUCTION}

Andrographis paniculata Nees. is an erect annual herbaceous plant in the familyAcanthaceae. It is extremely bitter in taste in all parts of the plant body. Andrographis paniculata commonly known as Kalmegh in Bengali. It is distributed in tropical Asian countries, often in isolated patches. It can be found in a variety of habitats, such as plains, hill slopes, wastelands, farms, dry or wet lands, sea shores and even road sides. The herb is available in Bangladesh, India, Pakistan, Malaysia, Sri Lanka and China. It has been used as medicinal herb in several traditional systems of medicine all over the world. It is extensively used in Ayurveda and Unani medicines as home remedy for various diseases (Sivarajan \& Balachandran, 1994). The therapeutic value of Kalmegh is due to its mechanism of action by enzyme induction. It is an important cold property herb, used in fevers and to dispel toxins from the body. It is used to treat gastrointestinal tract and upper respiratory infections, herpes, sore throat, hepatitis and a variety of other chronic and infectious diseases (Chopra et al., 1956; Purkayastha et al., 2008). It exhibits antibacterial, antimalarial, antidiarrhoeal, cardiovascular activities and protection of liver and gallbladder. The herb and its isolates like andrographolide, neoandrographolide, dehydroandrographolide etc. are reported to possess anti-inflammatory, hepatoprotective, astringent, anodyne, tonic and anti-pyretic properties and helps in arresting dysentery, cholera, diabetes, influenza, bronchitis and gonorrhoea ( Prajapati et al., 2003; Niranjan et al., 2010). Mass scale collection of this plant from natural habitats is leading to a depletion of plant resources. 
Conventional vegetative propagation of this important medicinal plant is very difficult and too slow to meet the commercial quantities required. Variability among the seedderived progenies and scanty and delayed rooting of seedlings curb its propagation via seeds (Martin, 2004; Prathanturarug et al., 1996).

In vitro propagation has proven as a potential technology for mass scale production of medicinal plant species (Lui and Li, 2001; Wawrosch et al., 2001; Martin, 2002, 2003; Azad et al., 2005; Faisal et al., 2003; Hassan \& Roy, 2005). The present investigation reports the in vitro propagation technique that can be used as a potential tool for large scale production of this medicinal plant.

\section{MATERIALS AND METHODS}

The study was conducted in the Plant Biotechnology and Genetic Engineering Laboratory, Institute of Food and Radiation Biology, Atomic Energy Research Establishment, Savar, Dhaka. Plant materials, namely shoot tips and nodal segments were collected from the garden of Plant Biotechnology and Genetic Engineering division. They were washed thoroughly with running tap water for $45 \mathrm{~min}$ and then with house hold detergent (Trix) to remove the traces of dust particles. Shoot tips and nodal segments were then surface sterilized with aqueous solution of $0.1 \% \mathrm{HgCl}_{2}$ for 6 min under aseptic conditions in laminar air flow cabinet and rinsed 4-5 times with autoclaved distilled water to wash away the traces of $\mathrm{HgCl}_{2}$ completely. After surface sterilization, shoot tips and nodal segments were divided into small pieces (approx. 1.0-1.5 cm). These were used as explants and cultured onto culture medium. MS (Murashige \& Skoog, 1962) containing $3 \%$ sucrose was used for all shoot regeneration studies. But half-strength MS was used for in vitro root formation. Shoot tip and nodal segment explants were cultured on MS supplemented with different cocentrations and combinations of cytokinins (BAP \& Kin) and auxin (NAA) for shoot regeneration. Media supplements such as coconut water (CW) (5-20\%) collected from local market and urea (Sigma) $(50-200 \mathrm{mg} / \mathrm{l})$ with constant cocentration of activated charcoal (AC) (Sigma) (2.0 g/l) were added to the medium for the determination of their effects on shoot multiplication and elongation respectively. Well developed shoots were excised from the elongation medium and cultured individually in rooting media containing different concentrations and combinations of IBA, IAA and NAA. The $\mathrm{pH}$ of the media was adjusted to 5.8 before adding agar. All media were gelled with $0.7 \%$ Difco Bacto agar and autoclaved for 20 min at $121^{\circ} \mathrm{C}$ under $1.1 \mathrm{~kg} / \mathrm{cm}^{2}$ pressure. The cultures were regularly sub-cultured at three weeks intervals on fresh medium. Cultures were maintained at $25 \pm 2^{\circ} \mathrm{C}$ with $16 \mathrm{~h}$ photoperiods. For hardening, the test tubes containing rooted shoots were kept at room temperature and light for 5 days. Thereafter, the well rooted plantlets were taken out from the test tubes and gently washed them to free from medium. After washing they were transferred to poly bags containing a mixture of soil, sand and compost in 2:1:1 ratio. They were finally transferred to experimental field for study of their mortality rate and growth in natural conditions. . 


\section{RESULTS AND DISCUSSION}

In vitro technique provides viable alternative method of mass production of healthy plants with uniform characteristics. Both shoot tip and nodal segment explants cultured on MS supplemented with different concentrations of BAP, Kin and NAA alone or in various combinations for multiple shoot regeneration. Between two types of explants, the best shoot induction rate was observed in nodal segment explant and it was $88 \%$ at the concentration of $11.10 \mu \mathrm{M} / 1 \mathrm{BAP}$ in MS medium (Table 1). In this combination, the regenerated shoots per explant was $18 \pm 1.24$ (Table 1, Fig. 1). In the same medium, multiple shoots induction from shoot tip explant was 15 \pm 1.22 (Table 1). Purkayastha et al. (2008) reported that MS medium supplemented with $10 \mu \mathrm{M} / 1$ BAP was optimum to regenerate multiple shoots in Andrographis paniculata from nodal explant. It is concluded that BAP combination is more effective on shoot proliferation from nodal explant of Andrographis paniculata. Addition of $10 \% \mathrm{CW}$ and $2.0 \mathrm{~g} / 1$ activated charcoal to the medium increased the number of shoots (30 in case of nodal explant) per culture (Fig. 2). Different concentrations of urea (50-200 mg/l) and constant concentration of activated charcoal $(2.0 \mathrm{~g} / \mathrm{l})$ were added to the medium to determination of their effects on shoot elongation. Addition of $100 \mathrm{mg} / 1$ urea and $2.0 \mathrm{~g} / \mathrm{l} \mathrm{AC}$ to the medium increased the length of shoots (Fig. 3). Roy (2008) reported that addition of $10 \% \mathrm{CW}$ in the medium increased the number of shoots in Boerhaavia diffusa L. culture. Rahman et al. (1999) also observed similar effect of $\mathrm{CW}(10 \%)$ on in vitro shoot multiplication of Emblica officinalis. Ahmed et al. (2001) reported that urea was fruitful media supplement for in vitro shoot elongation of Holarrhena antidysenterica $\mathrm{L}$.

Regenerated shoots need to root formation for their healthy growth. So, well developed and elongated shoots were excised and implanted in the rooting medium containing halfstrength MS with different concentrations and combinations of IBA, IAA and NAA. The best result was obtained in half-strength MS supplemented with $9.80 \mu \mathrm{M}$ IBA (Table 2). In this combination, it was observed that $90 \%$ shoots rooted well within three weeks of culture and each microcutting produced 28-30 roots (Fig. 4). Purkayastha et al. (2008) reported that IBA was more effective for in vitro rooting of Andrographis paniculata. They observed that MS supplemented with $2.5 \mu \mathrm{M} / \mathrm{l}$ IBA was suitable combination for best rooting. After sufficient development of roots, plantlets were transferred to poly bags containing a mixture of soil, sand and compost in 2:1:1 ratio (Fig. 5). The plantlets were kept in a shade and misted twice a day. After two weeks of hardening, plantlets were transferred to experimental field. Forty eight plantlets out of sixty were survived (i.e. $80 \%$ ) in natural conditions (Table 3).

In conclusion, I report an efficient and easy to handle protocol for rapid micropropagation of Andrographis paniculata. The application of this protocol can help minimize the pressure on wild population and contribute to the conservation of this important medicinal plant. 
Table 1. Effects of different concentrations and combinations of cytokinins (BAP, Kin) and auxin (NAA) on shoot proliferation of Andrographis paniculata Nees. from shoot tip and nodal segment explants

\begin{tabular}{|c|c|c|c|c|}
\hline \multirow{3}{*}{$\begin{array}{c}\text { Growth regulators } \\
\qquad(\mu \mathrm{M} / 1)\end{array}$} & \multicolumn{4}{|c|}{ Explants } \\
\hline & \multicolumn{2}{|c|}{ Shoot tip } & \multicolumn{2}{|c|}{ Nodal segment } \\
\hline & $\begin{array}{c}\% \text { of explants } \\
\text { produced } \\
\text { shoots }\end{array}$ & $\begin{array}{l}\text { Average No. of } \\
\text { shoots/ culture } \\
( \pm \mathrm{SE})\end{array}$ & $\begin{array}{c}\% \text { of explants } \\
\text { produced } \\
\text { shoots }\end{array}$ & $\begin{array}{c}\text { Average No. of } \\
\text { shoots/ culture } \\
( \pm \mathrm{SE})\end{array}$ \\
\hline \multicolumn{5}{|l|}{ BAP } \\
\hline 2.22 & - & - & - & - \\
\hline 4.44 & 30 & $4 \pm 0.22$ & 30 & $5 \pm 0.42$ \\
\hline 6.66 & 48 & $6 \pm 0.30$ & 40 & $6 \pm 0.34$ \\
\hline 8.88 & 60 & $10 \pm 1.12$ & 64 & $12 \pm 1.20$ \\
\hline 11.10 & 80 & $15 \pm 1.22$ & 88 & $18 \pm 1.24$ \\
\hline 13.32 & 50 & $10 \pm 0.90$ & 52 & $10 \pm 0.84$ \\
\hline 15.54 & 40 & $5 \pm 0.32$ & 40 & $6 \pm 0.82$ \\
\hline \multicolumn{5}{|l|}{ Kin } \\
\hline 2.32 & - & - & - & - \\
\hline 4.64 & - & - & - & - \\
\hline 6.96 & - & - & - & - \\
\hline 9.28 & 10 & $5 \pm 0.33$ & 20 & $6 \pm 0.24$ \\
\hline 11.60 & 30 & $8 \pm 0.48$ & 40 & $10 \pm 0.82$ \\
\hline 13.92 & - & - & 10 & $5 \pm 0.32$ \\
\hline 16.24 & - & - & - & - \\
\hline \multicolumn{5}{|l|}{ BAP+NAA } \\
\hline $2.22+1.34$ & - & - & - & - \\
\hline $4.44+1.34$ & - & - & - & - \\
\hline $6.66+1.34$ & 20 & $5 \pm 0.22$ & 30 & $5 \pm 0.62$ \\
\hline $8.88+1.34$ & 30 & $6 \pm 0.42$ & 38 & $8 \pm 0.48$ \\
\hline $11.10+1.34$ & 20 & $4 \pm 0.12$ & 20 & $4 \pm 0.22$ \\
\hline $13.32+1.34$ & - & - & - & - \\
\hline $6.66+2.68$ & - & - & - & - \\
\hline $8.88+2.68$ & 10 & $4 \pm 0.42$ & 28 & $5 \pm 0.12$ \\
\hline $11.10+2.68$ & - & - & - & - \\
\hline $13.32+2.68$ & - & - & - & - \\
\hline \multicolumn{5}{|l|}{ Kin+NAA } \\
\hline $4.64+2.68$ & - & - & - & - \\
\hline $6.96+2.68$ & 10 & $3 \pm 0.24$ & 30 & $5 \pm 0.24$ \\
\hline $9.28+2.68$ & 30 & $5 \pm 0.33$ & 34 & $5 \pm 0.42$ \\
\hline $11.60+2.68$ & 38 & $8 \pm 0.44$ & 40 & $6 \pm 0.75$ \\
\hline $13.92+2.68$ & 20 & $4 \pm 0.22$ & 20 & $3 \pm 0.22$ \\
\hline
\end{tabular}


Table 2. Effects of different concentrations of IBA, IAA and NAA singly or in combination in half-strength MS on root induction from regenerated shoot cuttings of Andrographis paniculata Nees

\begin{tabular}{|c|c|c|c|}
\hline Auxins $(\mu \mathrm{M} / \mathrm{l})$ & $\begin{array}{c}\% \text { of shoots } \\
\text { rooted }\end{array}$ & $\begin{array}{l}\text { Days required for } \\
\text { rooting }\end{array}$ & $\begin{array}{c}\text { No. of roots per } \\
\text { shoot }\end{array}$ \\
\hline \multicolumn{4}{|l|}{ IBA } \\
\hline 2.45 & 30 & $20-22$ & $10-12$ \\
\hline 4.90 & 50 & $20-22$ & $15-17$ \\
\hline 7.35 & 70 & $18-20$ & $18-20$ \\
\hline 9.80 & 90 & $15-17$ & 28-30 \\
\hline 12.25 & 50 & $18-20$ & $12-14$ \\
\hline 14.70 & 40 & $20-22$ & $10-12$ \\
\hline \multicolumn{4}{|l|}{ IAA } \\
\hline 2.85 & - & - & - \\
\hline 5.70 & - & - & - \\
\hline 8.55 & - & - & - \\
\hline 11.40 & 20 & $20-22$ & $12-14$ \\
\hline 14.25 & 10 & $20-22$ & $10-12$ \\
\hline 17.10 & - & - & - \\
\hline \multicolumn{4}{|l|}{ NAA } \\
\hline 2.86 & - & - & - \\
\hline 5.36 & - & - & - \\
\hline 8.04 & 20 & $18-20$ & $10-12$ \\
\hline 10.72 & 10 & $20-22$ & $08-10$ \\
\hline 13.40 & - & - & - \\
\hline 16.08 & - & - & - \\
\hline \multicolumn{4}{|l|}{ IBA+IAA } \\
\hline $4.90+2.85$ & 20 & $18-20$ & $12-14$ \\
\hline $7.35+2.85$ & 30 & $18-20$ & $14-16$ \\
\hline $9.80+2.85$ & 60 & $16-18$ & $18-20$ \\
\hline $12.25+2.85$ & 40 & $18-20$ & $12-14$ \\
\hline \multicolumn{4}{|l|}{$\mathbf{I B A}+\mathbf{I A A}+\mathbf{N A A}$} \\
\hline $4.90+2.85+2.68$ & 20 & $20-22$ & $10-12$ \\
\hline $7.33+5.70+2.68$ & 40 & $20-22$ & $12-14$ \\
\hline $9.80+8.55+5.36$ & 50 & $18-20$ & $16-18$ \\
\hline $12.25+11.40+8.04$ & 30 & $20-22$ & $10-12$ \\
\hline
\end{tabular}

Table 3. Survival rate of in vitro grown plantlets (Andrographis paniculata Nees) in experimental field

\begin{tabular}{c|c|c|c}
\hline Transferred steps & $\begin{array}{c}\text { No. of transferred } \\
\text { plantlets in experimental } \\
\text { field }\end{array}$ & $\begin{array}{c}\text { No. of survived } \\
\text { plantlets }\end{array}$ & $\begin{array}{c}\text { Average survived } \\
\text { plantlets (\%) }\end{array}$ \\
\hline Step-1 & 20 & 16 & \\
Step-2 & 20 & 14 & \multirow{2}{*}{$80 \%$} \\
Step-3 & 20 & 18 & \\
\hline Total & 60 & 48 & \\
\hline
\end{tabular}



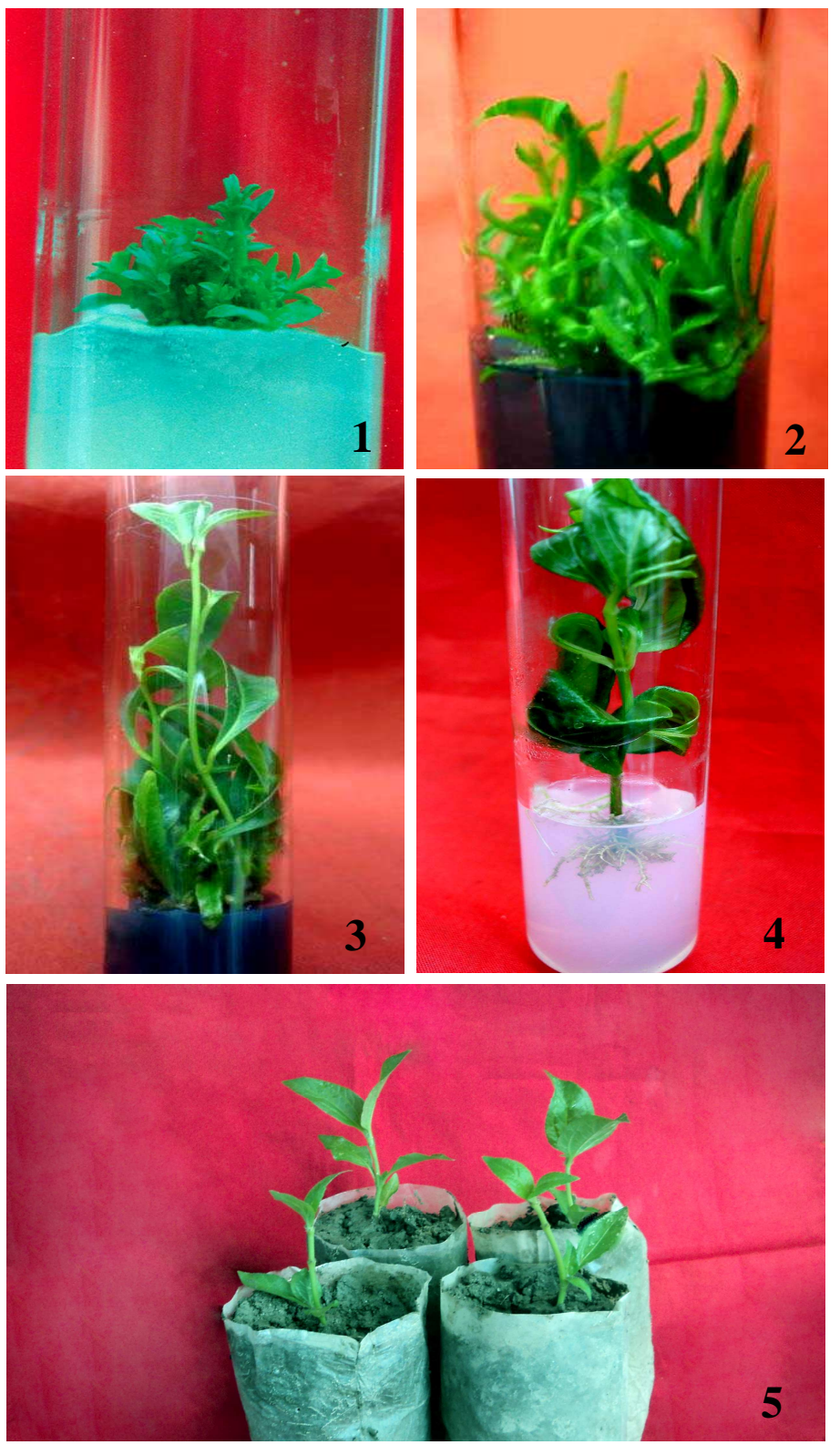

Figs. 1-5. In vitro regeneration of Andrographis paniculata Nees. 1. Multiple shoot formation from nodal explant on MS with $11.10 \mu \mathrm{M} / \mathrm{B}$ BAP. 2. Positive effect of coconut water $(10 \%)$ and activated charcoal $(2.0 \mathrm{~g} / \mathrm{l})$ on increase the number of shoots. 3 . Elongated shoots on MS supplemented with $11.10 \mu \mathrm{M} / \mathrm{l} \mathrm{BAP}, 100 \mathrm{mg} / \mathrm{l}$ urea and $2.0 \mathrm{~g} / \mathrm{l}$ AC. 4. In vitro root induction on half-strength MS supplemented with 9.80 $\mu \mathrm{M} /$ IBA. 5. Regenerated plantlets in poly bags containing soil, sand and compost $(2: 1: 1)$ 


\section{REFERENCES}

Ahmed, G., Roy, P.K. and Mamun, A.N.K. 2001. High frequency shoot regeneration from nodal and shoot tip explants in Holarrhena antidysenterica L. Indian J. Experimental Biol. 39: 1322-1324.

Azad, M.A.K., Yokota, S., Ohkubo, T., Andoh, Y., Yahara, S. and Yoshizawa, N. 2005. In vitro regeneration of the medicinal woody plant Phellodendron amurense Rupr. through excised leaves. Plant Cell Tiss. Org. Cult. 80: 43-50.

Chopra, R.N., Nayar, S.L. and Chopra, I.C. 1956. Glossary of Indian Medicinal Plants. NISCOM, CSIR, New Delhi, India. 18.

Faisal, M., Ahmad, N. and Anis, M. 2003. Shoot multiplication in Rauvolfia tetraphylla L. using thidiazuron. Plant Cell Tiss. Org. Cult. 80: 187-190.

Hassan, A.K.M.S. and Roy, S.K. 2005. Micropropagation of Gloriosa superba L. through high ferquency shoot proliferation. Plant Tissue Cult. 15(1): 67-74.

Lui, Z. and Li, Z. 2001. Micropropagation of Camptotheca acuminata from axillary buds, shoot tips and seed embryos in tissue culture system. In Vitro Cell. Dev. Biol. Plant. 37: 84-88.

Martin, K.P. 2002. Rapid propagation of Holostema ada-kodien Schuit.- a rare medicinal plant, through axillary bud multiplication and indirect organogenesis. Plant Cell Rep. 21: 112117.

Martin, K.P. 2003. Plant regeneration through somatic embryogenesis on Holostema ada-kodien Schult.- a rare medicinal plant. Plant Cell Tiss. Org. cult. 27: 79-82.

Martin, K.P. 2004. Plant regeneration protocol of medicinally important Andrographis paniculata Nees. via somatic embryogenesis. In vitro Cell Dev. Biol. Plant. 40: 204-209.

Murashige, T and Skoog, F. 1962. A revised medium for rapid growth and bioassys with tobacco tissue cultures. Physiol. Plant. 15(3): 473-497.

Niranjan, A., Tewari, S.K. and Lehri, A. 2010. Biological activities of Kalmegh (Andrographis paniculata Nees.) and its active principles- A review. Indian J. Natural Products and Reso. 1(2): $125-135$.

Prajapati, N.D., Purohit, S.S., Sharma, A.K. and Kumar T. 2003. A hand book of medicinal plants. Agrobios, Jodhpur, India. 45-46.

Prathanturarug, S., Schaffner, W., Buter, K.B. and Pank, F. 1996. In vitro propagation of the Thai medicinal plant Andrographis paniculata Nees. Proc. Int. symp. Breeding Research on Medicinal and Aerometic plants, Quedlinburg, Germany. 304-306.

Purkayastha, J., Sugla, T., Paul, A., Solleti, S. and Sahoo, L. 2008. Rapid in vitro multiplication and plant regeneration from nodal explants of Andrographis paniculata: A valuable medicinal plant. In Vitro Cell. Dev. Biol. Plant. 44: 442-447.

Rahman, M.M., Roy, P.K., Mannan, M.A. and Roy, S.K. 1999. Clonal propagation of Emblica officinalis through in vitro culture. Plant Tissue Cult. 9(1): 17-23.

Roy, P.K. 2008. Rapid multiplication of Boerhaavia diffusa L. through in vitro culture of shoot tip and nodal explant. Plant Tissue Cult.\& Biotech. 18(1): 49-56.

Sivarajan, V.V. and Balachandran, I. 1994. Ayurvedic drugs and their plant sources. New Delhi. Oxford \& IBH Publishing. 243-245.

Wawrosch, C., Malla, R.R. and Kopp, B. 2001. Clonal propagation of Lilium nepalense D. Don,- a threatened medicinal plant of Nepal. Plant Cell Rep. 10: 457-460. 